\title{
UJI KINERJA MICRO SPRINKLER TIPE G 360 DEGREE ROTARY
}

\section{(Performance Test of Sprinkle G 360 Degree Rotary Type)}

\author{
Kadek Endrayanti ${ }^{* *}$, Ahmad Munir ${ }^{2)}$, dan Samsuar ${ }^{3)}$ \\ ${ }^{1)}$ Program Studi Teknik Pertanian, Universitas Hasanuddin, Makassar \\ ${ }^{2)}$ Program Studi Teknik Pertanian, Universitas Hasanuddin, Makassar \\ ${ }^{3)}$ Program Studi Teknik Pertanian, Universitas Hasanuddin, Makassar \\ *) Email korespondensi: endrayanti30@yahoo.co.id
}

\begin{abstract}
ABSTRAK
Permasalahan air sangat berpengaruh terhadap lahan pertanian, pada musim kemarau kekurangan air dan kekeringan diberbagai wilayah. Permasalahan lainnya yaitu terbatasnya jumlah air yang dapat dieksplorasi dan dikonsumsi, sedangkan jumlah penduduk Indonesia yang terus bertambah menyebabkan kebutuhan air baku meningkat secara drastis. Irigasi mikro dapat menjadi pilihan untuk meningkatkan produktivitas lahan kering. Sistem irigasi ini hanya mengaplikasikan air disekitar perakaran tanaman. Salah satunya adalah micro sprinkler tipe $G$ 360 degree rotary. Tujuan dari penelitian ini yaitu mengetahui efisiensi keseragaman irigasi berdasarkan bentuk pola peletakan micro sprinkle tipe $G 360$ degree rotary sehingga dapat menjadi acuan bagi petani setempat dalam mengelola pemberian air pada tanaman untuk mengefisiensikan penggunaannya. Hasil yang diperoleh menunjukkan nilai rata-rata koefisien keseragaman (CU) pada pola segi empat sebesar $57,21 \%$ dan nilai rata-rata distribusi keseragaman (DU) sebesar 31,96\% sedangkan pada pola segi tiga menunjukkan nilai rata-rata koefisien keseragaman (CU) sebesar 50,34\% dan nilai rata-rata distribusi keseragaman (DU) sebesar 21,05 \% Kecilnya nilai CU dan DU disebabkan oleh rendahnya tekanan dan jarak tumpang tindih (overlapping) sehingga pendistribusian tidak merata.
\end{abstract}

Kata Kunci: Irigasi, Micro sprinkler, Micro sprinkle tipe G 360 degree rotary

\section{PENDAHULUAN}

\section{Latar Belakang}

Permasalahan air sangat berpengaruh terhadap lahan pertanian, pada musim kemarau kekurangan air dan kekeringan diberbagai wilayah. Permasalahan lainnya yaitu terbatasnya jumlah air yang dapat dieksplorasi dan dikonsumsi, sedangkan jumlah penduduk Indonesia yang terus bertambah menyebabkan kebutuhan air baku meningkat secara drastis. Masalah kualitas air semakin mempersempit alternatif sumber-sumber air yang bisa dimanfaatkan oleh masyarakat. Pemenuhan kebutuhan air merupakan salah satu faktor yang perlu diperhatikan, pemberian air yang tepat dan optimum disertai dengan pengelolaan jaringan irigasi yang baik akan menciptakan pertumbuhan tanaman yang optimum, sehingga hasil pertanian yang maksimal dapat tercapai. Pemberian air yang tepat yang sesuai dengan kebutuhan air tanaman maka dapat semakin cepat pertumbuhan dan perkembangan tanaman. Namun, bila jumlah air yang diberikan semakin banyak, kelebihan air menjadi tidak bermanfaat atau tidak efisien dan tentunya akan menjadi masalah bagi tanaman.

Irigasi mikro dapat menjadi pilihan untuk meningkatkan produktivitas lahan kering. Sistem irigasi ini hanya mengaplikasikan air disekitar perakaran tanaman. Salah satunya adalah micro sprinkler. Upaya pemenuhan kebutuhan air tanaman dilakukan untuk meningkatkan produktifitas yang dapat dilakukan dengan 
menggunakan irigasi sprinkler. Sistem irigasi sprinkler dapat memberikan efisiensi dan efektifitas yang cukup tinggi dalam memenuhi kebutuhan air bagi tanaman. Hal ini dapat terwujud jika sistem irigasi sprinkler dapat dirancang dengan tepat. Irigasi curah (sprinkler irrigation) salah satu metode irigasi dimana pemberian air dilakukan dengan menyemprotkan air ke udara kemudian jatuh ke permukaan tanah seperti halnya air hujan yang jatuh ke bumi.

Irigasi mikro adalah salah satu terobosan yang bisa dilakukan. Teknologi ini adalah suatu istilah bagi sistem irigasi yang mengaplikasikan air hanya disekitar zona penakaran tanaman. Sejauh ini irigasi mikro yang diterapkan adalah lebih banyak berdasarkan sistem dapat pemberian atas permukaan (Imanudin, 2015).

Pada sistem irigasi micro sprinkler, keseragaman pemberian air perlu diperhatikan untuk mengetahui efisiensi irigasi berdasarkan bentuk pola peletakan micro sprinkler dan melihat sejauh mana distribusi air tersebut dapat diterima oleh tanaman dengan sempurna. Hal ini dapat tercapai jika pemberian air pada lahan pertanian seragam. Oleh sebab itu untuk dapat mengetahui pola peletakan micro sprinkler yang efisiens digunakan, maka dilakukan penelitian ini. Untuk dapat mengetahui efisiensi keseragaman serta distribusi keseragamann irigasi micro sprinkler.

\section{Tujuan dan Kegunaan}

Tujuan penelitian ini yaitu untuk mengetahui koefisien keseragaman dan distribusi keseragaman irigasi berdasarkan bentuk pola peletakan micro sprinkle type $G$ 360 degree rotary.

Kegunaan penelitian ini adalah sebagai acuan dalam pengelolaan irigasi menggunaan mikro sprinkler tipe $G 360$ degree rotary dalam mengefisienkan penggunaannya.

\section{METODE PENELITIAN}

\begin{abstract}
Alat
Alat yang digunakan pada penelitian ini yaitu wadah (catch-can) untuk menampung air, gelas ukur digunakan untuk mengukur volume air yang tertampung pada catch-can, stopwatch, meteran digunakan untuk mengukur jarak antara micro sprinkler dan jarak atara catch-can, anemometer digunakan untuk mengukur kecepatan angin, dan pressure gauge digunakan untuk mengukur tekanan.
\end{abstract}

\section{Bahan}

Bahan yang digunakan pada penelitian ini adalah pipa digunakan untuk menyalurkan air dari penampungan kepompa, selang digunakan untuk menyalurkan air dari pompa ke micro sprinkler, sambungan selang digunakan untuk menyambungkan selang utama ke selang lateral (selang tempat diletakan pencurah micro sprinkler), micro sprinkler tipe $G 360$ degree rotary, air.

\section{Prosedur Penelitian}

Penelitian Penelitian uji kinerja irigasi micro sprinkler ini dilakukan dengan langkah-langkah sebagai berikut:

a) Pengambilan Data

1. Prosedur pengukuran uji kinerja irigasi micro sprinkler adalah:

2. Menyiapkan alat dan bahan.

3. Membuat rancangan irigasi micro sprinkler pola segi empat dengan menggunakan 8 micro sprinkler dan segi tiga menggunakan 7 micro sprinkler.

4. Meletakkan wadah disekitar micro sprinkler dengan jarak $60 \mathrm{~cm}$.

5. Mengoperasikan sistem irigasi sprinkler selama 30 menit pada setiap masingmasing pola kemudian diukur:

a. Volume air tertampung dalam wadah

b. Diameter kaleng

c. Jarak pancaran (jangkauan terjauh)

6. Melakukan pengulangan pengujian selama 3 kali.

b) Pengolahan dan Analisis Data

Pada tahap ini dilakukan analisis

kebutuhan sistem yang meliputi: 
1. Parameter yang diamati
a. Tebal air tertampung tiap satuan waktu
b. Tekanan
c. Jarak pancaran
d. Arah Angin
e. Kecepatan Angin

2. Tingkat keseragaman penyebaran air dinilai dengan menggunakan indeks $\mathrm{CU}$ (coefficient uniformity) yaitu:

Dimana:

$$
C U=\left[1,0-\frac{\sum I X i-x I}{x n}\right] \times 100 \%
$$

$C U=$ Koefisiens keragaman $(\%)$

$\mathrm{Xi}=$ Nilai setiap pengamatan (cc)

$\mathrm{X}=$ Nilai rata-rata pengamatan (cc)

3. Distribusi Penyebaran air

Tingkat Distribusi penyebaran air dinilai dengan menggunakan indeks DU (distribution uniformity):

$$
D U=100-1,59(100-C U)
$$

Dimana :

DU $=$ Koefisien distribusi $(\%)$

$\mathrm{CU}=$ Koefisien keseragaman $(\%)$

4. Laju Penyiraman dapat dinyatakan dengan persamaan 4 yaitu:

Dimana:

$$
I=\frac{K x q}{\operatorname{SexSl}}
$$

$\mathrm{I}=$ Laju penyiraman rat-rata $(\mathrm{mm} / \mathrm{jam})$

$\mathrm{K}=$ faktor konfensi sebesar 60

$\mathrm{q}=$ Debit sprinkler ( $1 /$ menit)

$\mathrm{Se}=$ Jarak sprinkler dalam laterar $(\mathrm{m})$

$\mathrm{Sl}=$ Jarak antar lateral $(\mathrm{m})$

5. Kontur Siraman dan Visualisasi 3D

6. Profil Siraman

\section{HASIL DAN PEMBAHASAN}

\section{Evaluasi Kinerja Jaringan Irigasi Mikro} Sprinkler Tipe G 360 Degree Rotary

Evaluasi sebaran micro sprinkler terdiri dari koefisien keseragaman dan keseragaman distribusi. Pada perhitungan koefisien keseragaman, distribusi keseragaman dan laju aplikasi dilakukan pada titik pengamatan yang berjumlah 160 catch-can yang tersebar pada masingmasing micro sprinkler dengan pola peletakan segi empat dan pola peletakan segi tiga. Layout evaluasi kinerja sprinkler dapat dilihat pada Gambar berikut:

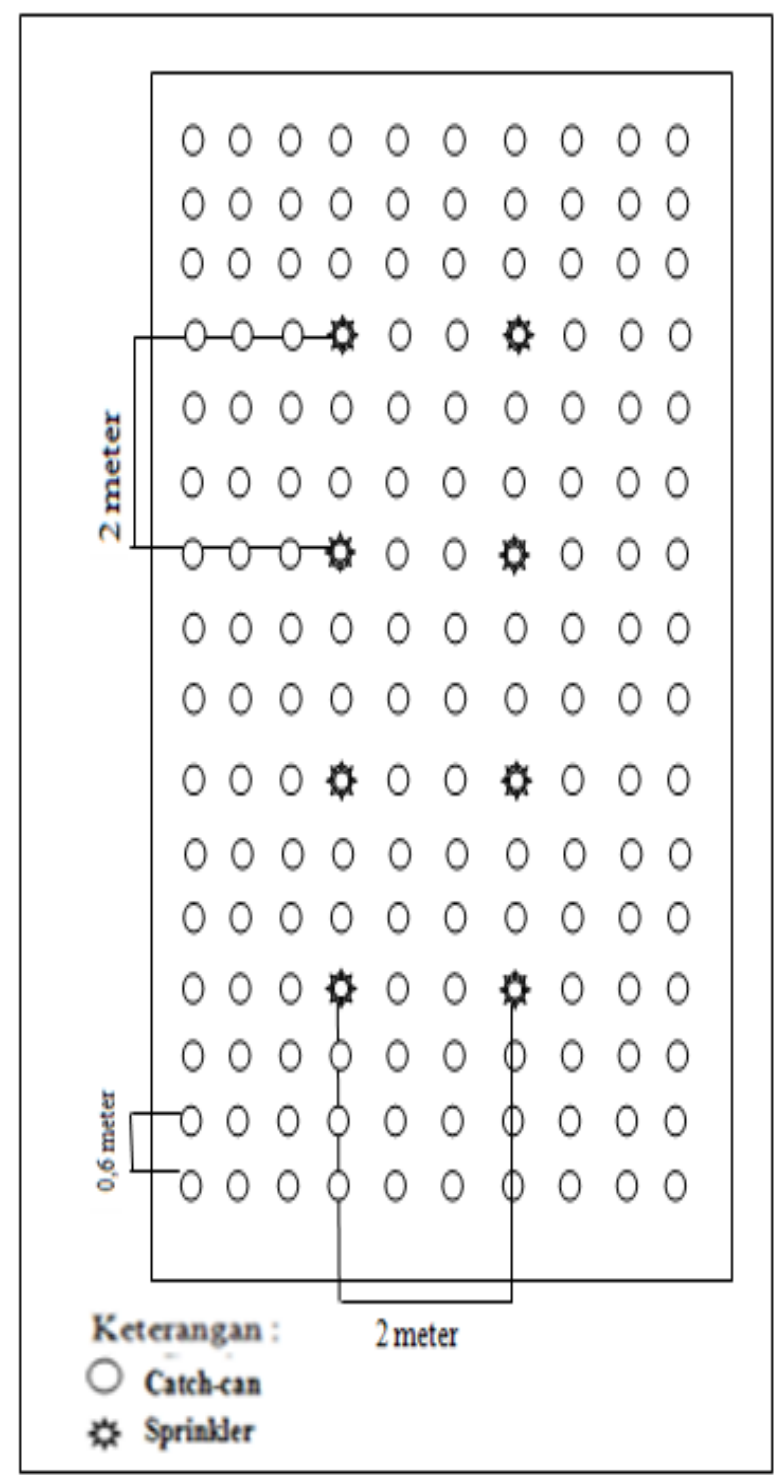

Gambar 1. Layout jaringan irigasi micro sprinkler dengan pola segi tiga. 


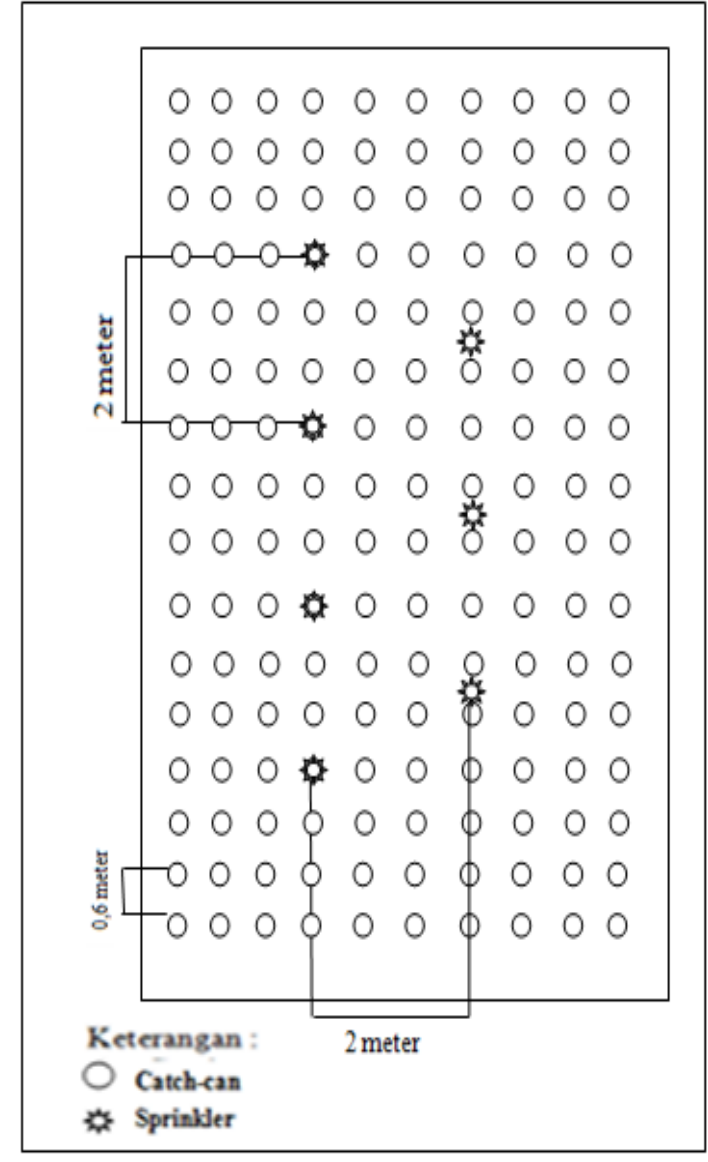

Gambar 3. Layout jaringan irigasi micro sprinkler dengan pola segi empat.

Pada pengujian pendahuluan menunjukkan radius pancaran pada micro sprinkler tipe $\mathrm{G} 360$ degree rotary yaitu $2 \mathrm{~m}$ dengan tinggi micro sprinkler $50 \mathrm{~cm}$. Kondisi tersebut sesuai dengan radius yang diinginkan yaitu $0,6 \mathrm{~m}$ sehingga memungkinkan setiap sprinkler memenuhi kebutuhan air pada 160 catch-can. Evaluasi kinerja sprinkler sangat dipengaruhi oleh tekanan, kecepatan angin, jarak sprinkler dan topografi lahan. Semakin tinggi tekanan menyebabkan air yang keluar dari nozel pada sprinkler menjadi merata selama masih dalam batas yang ditetapkan. Tetapi apabila tekanan yang dipakai terlalu tinggi, akan menyebabkan air yang keluar dari nozel menjadi butiran yang sangat halus yang mudah terbawa oleh angin.Hasil perhitungan Debit rata-rata catch-can, nilai koefisien keseragaman (CU), keseragaman distribusi (DU), dapat dilihat pada Tabel 1 dan 2.
Tabel 1. Hasil Perhitungan Nilai Koefisien Keseragaman (CU), Keseragaman distribusi (DU) dan Laju Penyiraman pada Pola Segi Empat

\begin{tabular}{ccc}
\hline Percobaan & $\begin{array}{c}\text { Koefisien } \\
\text { keseragaman } \\
(\mathbf{\%})\end{array}$ & $\begin{array}{c}\text { Distribusi } \\
\text { keseragaman } \\
(\mathbf{\%})\end{array}$ \\
\hline 1 & 51.44 & 22.79 \\
2 & 60.17 & 36.67 \\
3 & 60.02 & 36.43 \\
\hline Rata-rata & 57.21 & 36.43 \\
\hline Debit & $: 1.17 \mathrm{l} / \mathrm{menit}$ & \\
Laju Penyiraman & $: 4.38 \mathrm{~mm} / \mathrm{jam}$ & \\
\hline
\end{tabular}

Tabel 2. Hasil Perhitungan Nilai Koefisien Keseragaman (CU), Keseragaman distribusi (DU) dan Laju Penyiraman pada Pola Segi Tiga

\begin{tabular}{ccc}
\hline Percobaan & $\begin{array}{c}\text { Koefisien } \\
\text { keseragaman } \\
(\boldsymbol{\%})\end{array}$ & $\begin{array}{c}\text { Distribusi } \\
\text { keseragaman } \\
(\boldsymbol{\%})\end{array}$ \\
\hline 1 & 50.51 & 21.31 \\
2 & 50.15 & 20.75 \\
3 & 50.18 & 20.79 \\
\hline Rata-rata & 50.28 & 20.95 \\
\hline Debit & $: 1.021 / \mathrm{menit}$ & \\
Laju Penyiraman & $: 3.82 \mathrm{~mm} / \mathrm{jam}$ & \\
\hline
\end{tabular}

Pada Tabel 1 dan 2 menampilkan Hasil perhitungan nilai koefisien keseragaman (CU) pada masing-masing pola peletakan micro sprinkler tipe $\mathrm{G} 360$ degree rotary dengan pengulangan sebanyak 3 kali. Nilai koefisien keseragaman tertinggi diperoleh pada Pola segi empat percobaan kedua dengan sebesar $60,17 \%$ dan terendah pada pola segi tiga pecobaan ketiga sebesar $50,18 \%$. Dengan hasil perhitungan nilai koefisien keseragaman (CU) 50,15\% $60,17 \%$ maka dapat diartikan bahwa penyiraman menggunakan sprinkler memiliki keseragaman penyiraman yang kurang baik karena lebih rendah dari $80 \%$. Menurut Prastowo (2010) efisiensi irigasi curah dapat diukur berdasarkan keseragaman pemberian air dari pencuran. Apabila penyebaran air tidak seragam (keseragaman rendah) maka dikatakan efesiensi irigasi curah rendah. Parameter yang umum digunakan untuk mengevaluasi keseragaman penyebaran air adalah koefisien keseragaman (coefficient of unformity-CU). Efesiensi irigasi curah yang 
tergolong tinggi (keseragaman tergolong baik) adalah nilai CU lebih besar dari $80 \%$.

Jarak sprinkler dapat berpengaruh terhadap nilai koefisien keseragaman. Penempatan jarak antara sprinkler disesuaikan dengan kecepatan angin. Menurut Tusi (2016) spasi sprinkler (kondisi normal yaitu $50 \%-65 \%$ dari diameter terbasahi. Pada uji pendahuluan micro sprinkler dalam kondisi normal atau volume air yang dipancarkan pada jarak dekat dengan sprinkler berjumlah lebih banyak dan semakin berkurang dengan bertambahnya jarak pancar. Pada penelitian ini tumpang tindih (overlapping) yaitu $50 \%$ utuk mengatasi pengaruh kecepatan angin.

Pada pola segi empat percobaan pertama, kedua dan ketiga koefisien keseragaman yang berbeda-beda. Pada percobaan pertama koefisien keseragamanya sebesar $51,44 \%$ dengan kecepatan angin mencapai 0,1-1,9 m/s dengan arah angin yang cenderung tidak berubah. Sedangkan pada percobaan 2 dan 3 dengan kecepatan angin mencapai $0,1-1,5$ $\mathrm{m} / \mathrm{s}$ dengan arah angin yang berubah dalam jelang waktu yang tidak terlampau lama. Pada pola segitiga nilai koefisien keseragaman lebih rendah dibandingkan dengan nilai koefisien keseragaman pada pola segi tiga yaitu pada percobaan pertama koefisien keseragaman sebesar 50,51\%, percobaan kedua koefisien keseragaman sebesar 50,15\% dan pada percobaan ketiga koefisiens keseragaman sebesar 50,18\% Tingkat perbedaan pada masing-masing percobaan tidak terlampau jauh dengan kecepatan angin yang mencapai $0,1-1,5 \mathrm{~m} / \mathrm{s}$. Rendahnya kecepatan angin tidak berpengaruh besar terhadap koefisien keseragaman (CU) dan keseragaman distribusi (DU). Menurut Utami (2013) Rendahnya kecepatan angin tidak berpengaruh besar terhadap koefisien keseragaman (CU) dan keseragaman distribusi (DU) menjadi rendah yang juga menyebabkan nilai efesiensi menjadi rendah juga. Pengukuran nilai koefisien keseragaman (CU) dan keseragaman distribusi (DU) sebaiknya dilakukan saat keceatan angin rendah.

Dengan mengunakan 8 micro sprinkler tipe $\mathrm{G} 360$ degree rotary pada pola segi empat dan 7 micro sprinkler tipe G 360 degree rotary pada pola segi tiga. Tumpang tindih (overlapping) $50 \%$ dari diameter terbasahi, sehingga overlapping terjadi pada bagian tengah yang menyebabkan banyaknya air yang tertampung pada bagian overlapping.

Pada tabel 1 dan 2 diketahui nilai keseragaman distribusi terbesar pada pola segi empat percobaan kedua yaitu $36.67 \%$. Kemudian, diikuti oleh pola segi empat percobaan ketiga sebesar $36.43 \%$ dan pada pola segi empat percobaan pertama sebesar $22.79 \%$. Pada pola segitiga nilai distribusi keseragamannya yaitu pada percobaan pertama sebesar $21.31 \%$, pada percobaan kedua sebesar $20.75 \%$, dan pada percobaan ketiga sebesar 20.79\%. Dengan hasil perhitungan nilai distribusi keseragaman (DU) yang berkisar antara 20,75\% - 36,67\%, maka dapat diartikan bahwa penyiraman menggunakan sprinkler memiliki distribusi keseragaman yang kurang baik.

Pada pola segi tiga nilai keseragaman pemberian air lebih rendah dibandingkan dengan nilai keseragaman pemberian air pada pola segi empat yang ditunjukan pada nilai rata-rata koefisien keseragaman pada pola segi empat sebesar $57,21 \%$, nilai ratarata keseragaman distribusi sebesar 31,96\% dan nilai rata-rata laju penyiraman sebesar $5,95 \mathrm{~mm} / \mathrm{jam}$. Nilai rata-rata koefisien keseragaman pada pola segi tiga sebesar $50,28 \%$, nilai rata-rata keseragaman distribusi sebesar 20,95\% dan nilai rata-rata laju penyiraman sebesar $4,87 \mathrm{~mm} / \mathrm{jam}$. Perbedaan nilai keseragaman pemberian air dapat dilihat pada gambar berikut ini: 


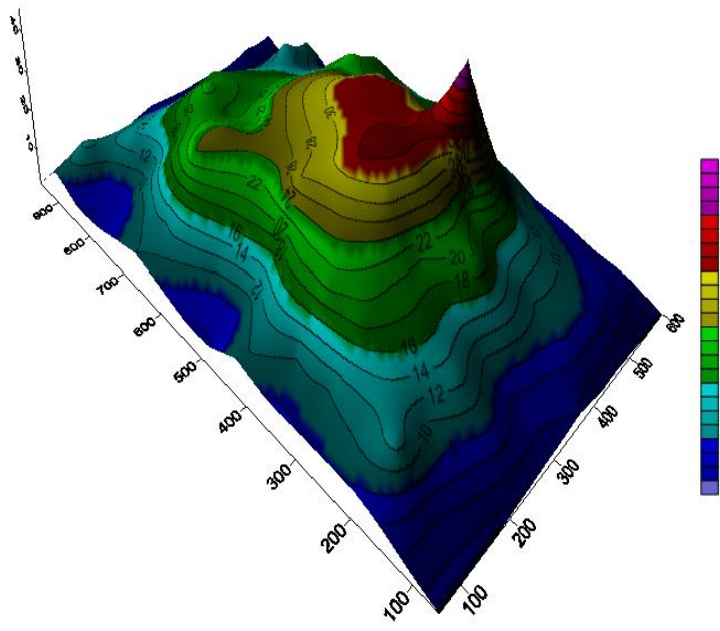

Gambar 4. Kontur 3 dimensi keseragaman pemberian air dengan pola peletakan segi empat pada percobaan pertama.

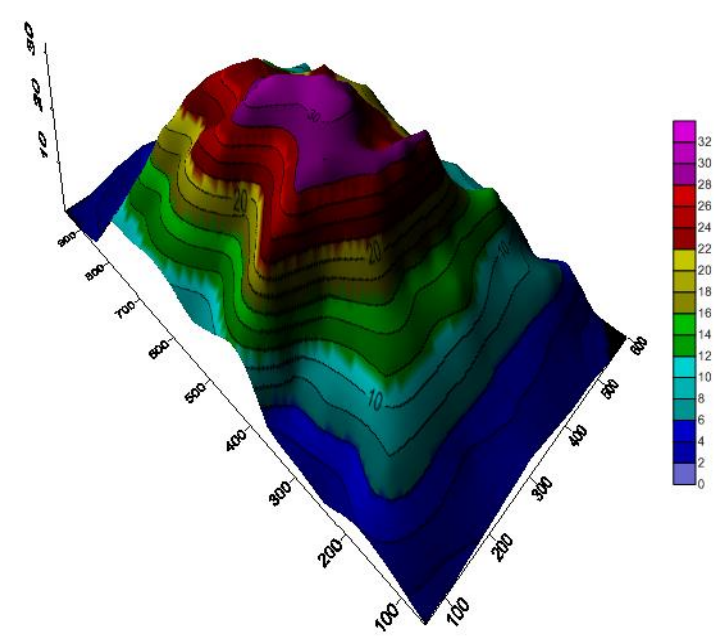

Gambar 5. Kontur 3 dimensi keseragaman pemberian air dengan pola peletakan segi empat pada percobaan kedua.

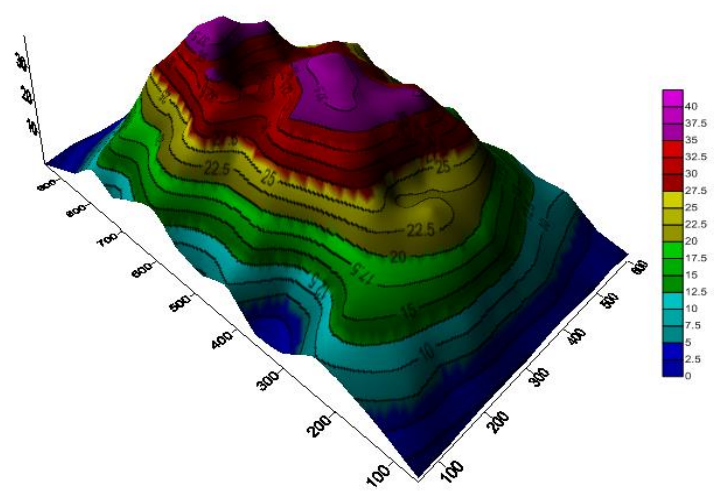

Gambar 6. Kontur 3 dimensi keseragaman pemberian air dengan pola peletakan segi empat pada percobaan ketiga.

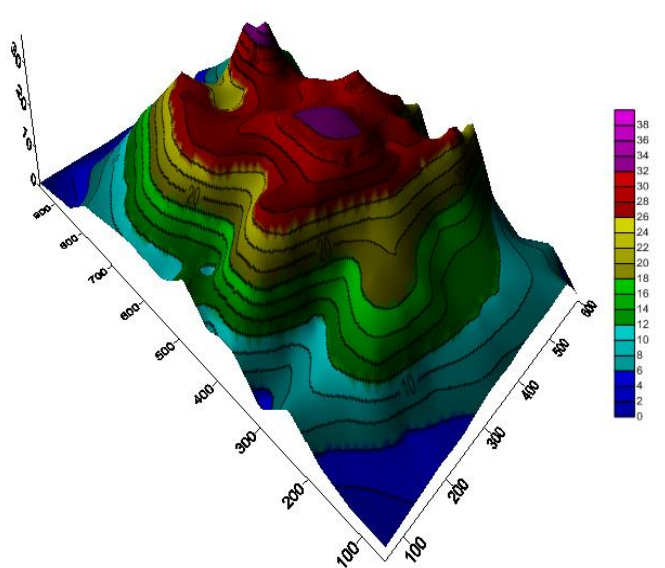

Gambar 7. Kontur 3 dimensi keseragaman pemberian air dengan pola peletakan segi tiga pada percobaan pertama.

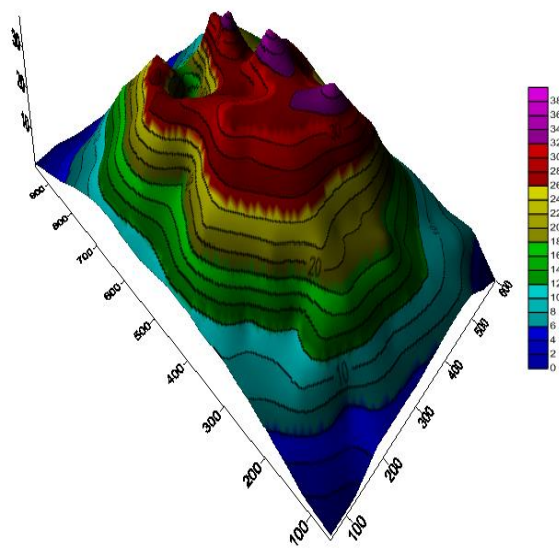

Gambar 8. Kontur 3 dimensi keseragaman pemberian air dengan pola peletakan segi tiga pada percobaan Kedua.

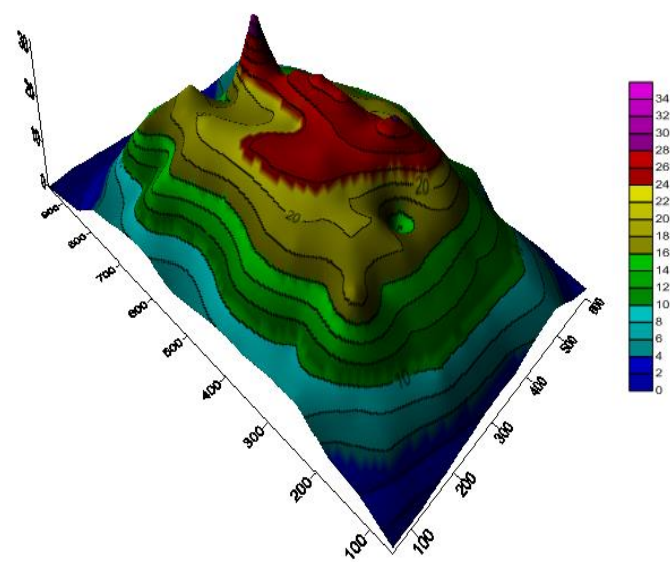

Gambar 9. Kontur 3 dimensi keseragaman pemberian air dengan pola peletakan segi tiga pada percobaan ketiga. 


\section{Pofil Siraman}

Berbedanya nilai koefisien keseragaman dan distribusi keseragaman untuk masing-masing percobaan pada pola segi empat maupun segi tiga dipengaruhi oleh arah angin, kecepatan angin, tekanan dan jarak antar sprikler. Pompa yang digunakan pada penelitian ini yaitu pompa shimizu tipe ps-135E tekanan pada pipa utama sebesar $2 \mathrm{kPa}$. Variasi voleme yang dihasilakn pada setiap jarak dapat dilihat pada grafik profil siraman berikut ini :

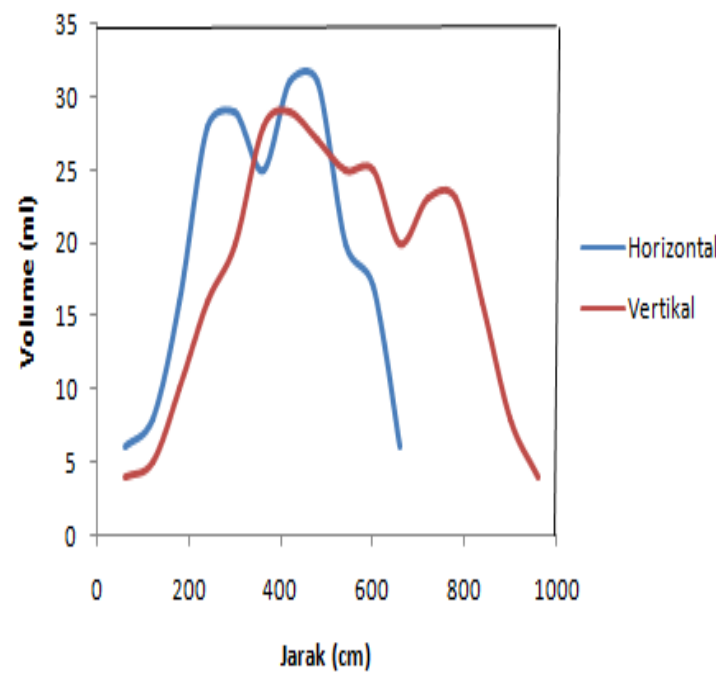

Gambar 10. Grafik profil siraman pada pola segi empat percobaan pertama.

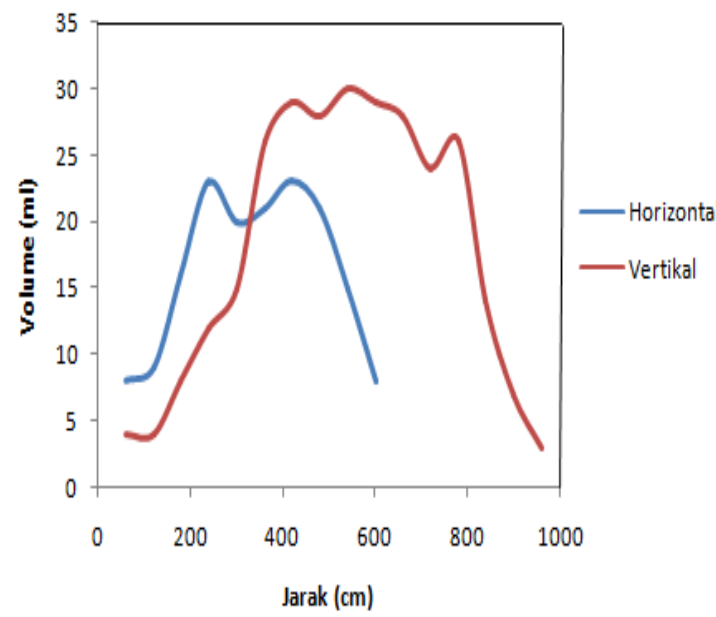

Gambar 11. Grafik profil siraman pada pola segi empat percobaan kedua.

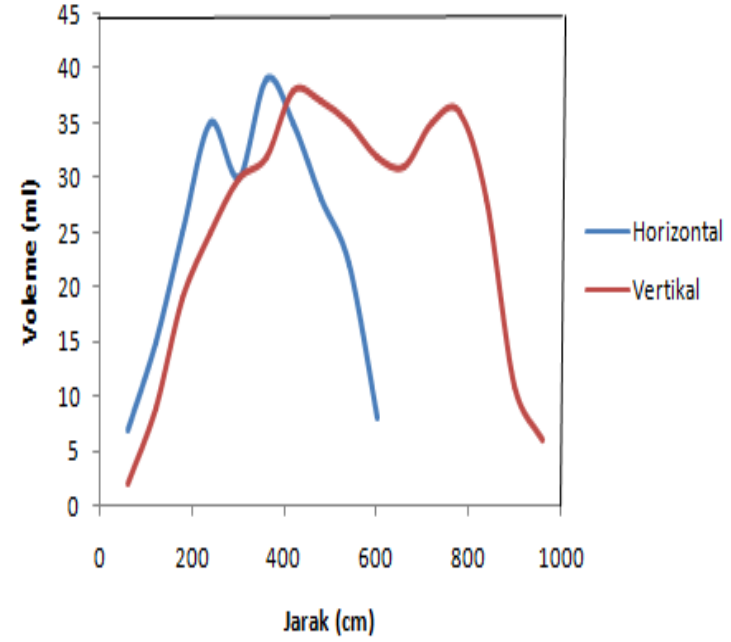

Gambar 12. Grafik profil siraman pada pola segi empat percobaan ketiga.

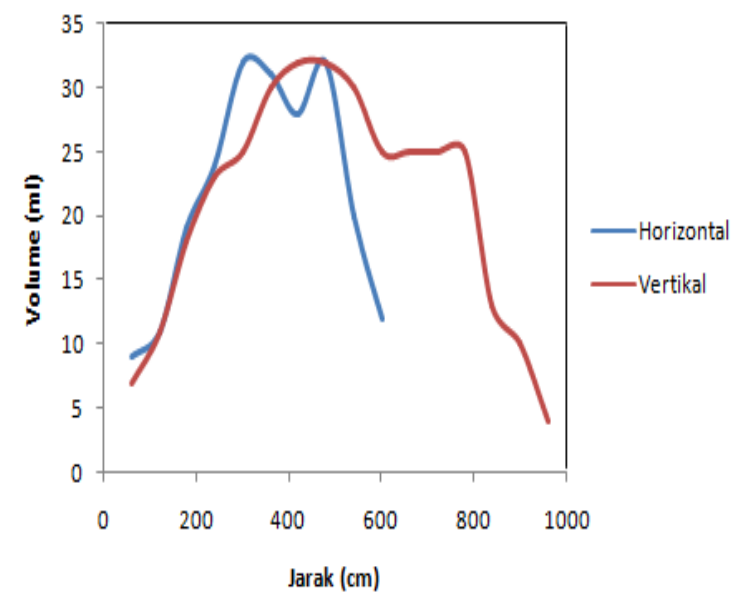

Gambar 13. Grafik profil siraman pada pola segi tiga percobaan pertama.

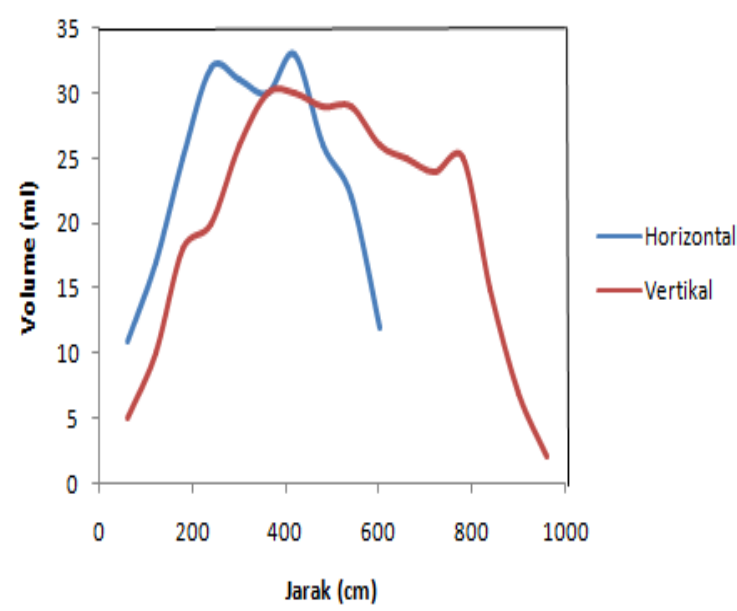

Gambar 14. Grafik profil siraman pada pola segi tiga percobaan Kedua. 


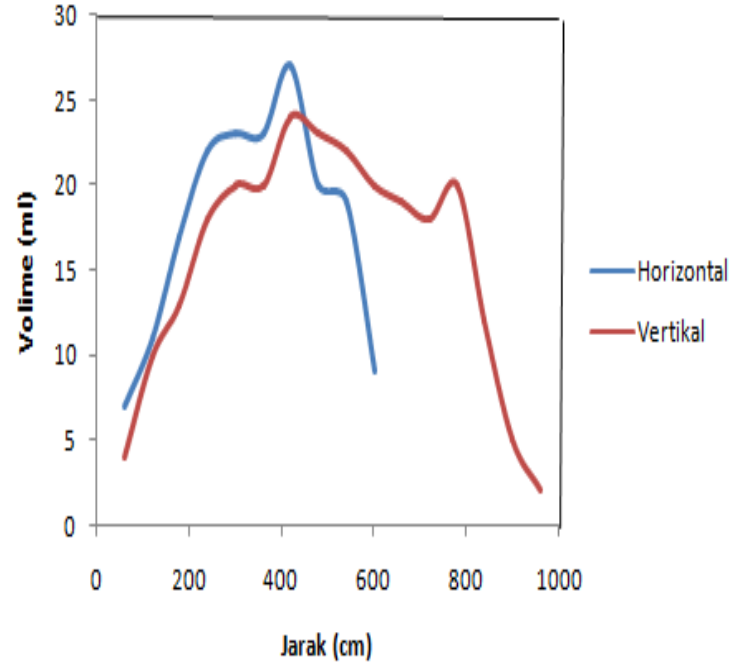

Gambar 15. Grafik profil siraman pada pola segi tiga percobaan ketiga.

Pada grafik profil siraman pada pola segi empat percoban pertama pendistribusian air meningkat pada kisaran jarak $200 \mathrm{~cm}$ sampai dengan $400 \mathrm{~cm}$ untuk bagian horizontal. Pada bagian vertikal jumlah volume air semakin meningkat pada jarak $400 \mathrm{~cm}$ sampai dengan $600 \mathrm{~cm}$. Hal ini menunjukkan bahwa pada bagian tersebut adalah bagian overlapping. Begitu pula pada grafik profil siraman pada pola segi empat percoban keduan dan ketiga. Namun pada jarak $60 \mathrm{~cm}$ sampai denga $200 \mathrm{~cm}$ jumlah volume air jauh berbeda yaitu pada percobaan kedua bagian vertikal volume pada jarak $60 \mathrm{~cm}$ yaitu $6 \mathrm{ml}$, pada jarak 120 yaitu $9 \mathrm{~cm}$ sedangkan pada bagian horizontal pada jarak $60 \mathrm{~cm}$ volume air sebanyak 8 dan pada jarak 120 sebanyak $15 \mathrm{~cm}$. Dapat dilihat yang grafik profil siraman pola segi empat pada percobaan kedua dan ketiga tidak saling menindih.

Pada grafik profil siraman pada pola segi tiga percoban pertama pendistribusian air meningkat dari jarak $240 \mathrm{~cm}$ sampai dengan $400 \mathrm{~cm}$ untuk bagian horizontal. Pada bagian vertikal jumlah volume air semakin meningkat pada jarak $420 \mathrm{~cm}$ sampai dengan $600 \mathrm{~cm}$. Hal ini menunjukkan bahwa pada bagian tersebut adalah bagian overlapping. Begitu pula pada grafik profil siraman pada pola segi empat percoban keduan dan ketiga. Namun pada jarak $60 \mathrm{~cm}$ sampai dengan $200 \mathrm{~cm}$ jumlah volume air jauh berbeda yaitu pada percobaan kedua bagian vertikal volume pada jarak $60 \mathrm{~cm}$ yaitu $6 \mathrm{ml}$, pada jarak 120 yaitu $8 \mathrm{~cm}$ sedangkan pada bagian horizontal pada jarak $60 \mathrm{~cm}$ volume air sebanyak 8 dan pada jarak 120 sebanyak $12 \mathrm{ml}$. Dapat dilihat yang grafik profil siraman pola segi empat pada percobaan kedua dan ketiga tidak saling menindih.

\section{KESIMPULAN DAN SARAN}

Berdasarkan hasil penelitian, dapat diambil kesimpul bahwa:

1. Nilai rata-rata koefisien keseragaman pada pola segi empat sebesar $57,21 \%$ dan nilai rata-rata koefisien keseragaman pada pola segi tiga sebesar 50,34\%. Nilai koefisien keseragaman kurang dari $80 \%$, hal ini menunjukkan tingkat pemberian air kurang terdistribusi merata.

2. Nilai koefisien keseragaman yang diperoleh pada pola peletakan micro sprinkler segi empat lebih tinggi dibandingkan dengan pola peletakan micro sprinkler segi tiga.

\section{DAFTAR PUSTAKA}

Imanudin, Momon Sidik., Prayitno. 2015. Pengembangan Irigasi Bawah Tanah Untuk Irigasi Mikro Melalui Metoda Kapilaritas Tanah. Universitas Sriwijaya. Palembang.

Prastowo. 2010. Irigasi Curah Teori dan Aplikasi. Bogor : IPB Press.

Utami, Ade tri. 2013. Studi Perencanaan Irigasi Curah Menggunakan Mikro SprinklerPada Tanaman Padi (Oryza Sativa L.). Palembang. Universitas Sriwijaya.

Tusi, Ahmad dan Budianto Lanya. 2016. Rancangan Irigasi Sprinkler Portable Tanaman Pakchoy. Lampung: Universitas Lampung. 